Diabetologia 7, 102-106 (1971)

(C) by Springer-Verlag 1971

\title{
Comparison of the Progress of Flat New Vessels on the Optic Dise with those on the Retina in Patients Treated by Pituitary Ablation
}

\author{
R.S. ElkeLes, R.K. BLACH and G.F. JoPLIN
}

Department of Medicine, Royal Postgraduate Medical School, London, Great Britain

Received: July 14, 1970, accepted: January 21, 1971

\begin{abstract}
Summary. The progress of new vessels arising on the disc has been compared with the progress of new vessels arising elsewhere on the retina from photographs of 29 eyes from 23 patients followed for a mean period. of 14 months. Only new vessels flat on the dise and unassociated with significant fibrosis were studied. Progress of the new vessesls in each of these two locations was based on grading of severity from corresponding sets of standard photographs. The direction of change whether regression or deterioration, was found to be the same for disc vessels and retinal vessels in all but one eye. It was found that this similarity in behaviour of new vessels in the two locations applied equally to the 22 eyes of 16 patients treated. by pituitary ablation where the direction of change was usually improvement, and to the 7 eyes of 7 nonoperated patients in which there was usually either no change or deterioration. Vitreous haemorrhage precluded a second assessment of 6 further operated and 3 further control eyes. - Disc vessels improved in 16 of the 22 assessable eyes from patients treated by pituitary ablation. Thus, the presence and type of new vessels on the dise should be one of the features assessed in a patient with diabetic retinopathy being considered for treatment with pituitary ablation.
\end{abstract}

Comparaison de l'évolution de nouveaux vaisseaux plats sur la papille optique avec ceux situés sur la rétine chez des patients traités par ablation de l'hypophyse

Résumé. L'évolution de nouveaux vaisseaux apparaissant sur la papille optique a été comparée à celle de nouveaux vaisseaux apparaissant sur la rétine, à partir de photographies de 29 yeux de 23 patients suivis pendant une période moyenne de 14 mois. Seuls les nouveaux vaisseaux plats sur la papille et non associés à une fibrose importante ont été étudiés. L'évolution de ces nouveaux vaisseaux dans chacun des deux endroits a été basée sur le degré de gravité à partir de séries correspondantes de photographies standard. La modification dans le sens soit d'une régression, soit d'une détérioration, était la même pour les vaisseaux de la papille et les vaisseaux de la rétine dans tous les yeux sauf un. Il a été trouvé que cette similitude dans le comportement des nouveaux vaisseaux aux deux endroits s'appliquait également aux 22 yeux des 16 patients traités par l'ablation de l'hypophyse chez lesquels la modification était habituellement une améliora- tion, et aux 7 yeux des 7 patients non-opérés chez lesquels il y avait généralement soit pas de modification, soit une détérioration. Une hémorragie vitreuse a empêché une seconde évaluation chez 6 autres opérés et 3 autres yeux témoins. - Les vaisseaux de la papille optique s'améliorèrent dans 16 des 22 youx étudiés de patients traités par l'ablation de l'hypophyse. Ainsi, la présence et le type de nouveaux vaisseaux sur la papille doit être une des caractéristiques évaluées chez un patient atteint de rétinopathie diabétique chez lequel un traitement par ablation de l'hypophyse est envisagé.

Vergleich des Fortschreitens neuer facher Gefäße auf der Papille und auf der Retina bei durch Hypophysektomie behandelten Patienten

Zusammenfassung, Das Fortschreiten neuer Gefäße auf der papilla nervi optici wurde mit der Entwicklung von Gefäßneubildungen an anderen Stellen der Netzhaut mit Hilfe der Fotografien von 29 Augen bei 23 Patienten über einen Zeitraum von i.D. 14 Monaten verglichen. Es wurden nur Gefäße untersucht, die der Papille flach auflagen und nicht mit wesentlicher Fibrose einhergingen. Das Fortschreiten der Gefäße an diesen beiden Stellen wurde mit Hilfe einer aus vergleichbaren Standardfotos abgeleiteten Skala beurteilt. Die Richtung der Veränderung im Sinne einer Rückbildung oder Verschlimmerung stimmten für die Papillen- und Netzhautgefäße bei allen Augen mit einer Ausnahme überein. Dieses ähnliche Verhalten der neuen Gefäße an beiden Stellen fand sich auch bei 22 Augen von 16 Patienten nach Hypophysektomie, bei denen die Veränderungen in der Regel auf eine Besserung hinausliefen und bei 7 Augen von 7 nichtoperierten Patienten, bei denen es zu Verschlechterungen oder keiner Befundänderung gekommen war. Glaskörperblutungen verhinderten die Nachuntersuchungen bei 6 weiteren operierten und 3 Vergleichs-Augen. - Die Papillengefäße besserten sich bei 16 von $22 \mathrm{zu}$ beurteilenden Augen von hypophysektomierten Patienten. Man sollte daher das Vorhandensein und den Typ neuer Gefäße auf der Papille überprüfen, wenn man bei einem Patienten mit diabetischer Retinopathie die Hypophysektomie orwägt.

Key-words. New vessels, optic disc, diabetic retinopathy, pituitary ablation.

\section{Introduction}

The presence of new vessels in diabetic retinopathy implies a lesion, potentially reversible, which may threaten vision by further extension, haemorrhage and progression to retinitis proliferans. In a series of 51 patients with diabetic retinopathy with new vessels present yet good initial vision, Deckert et al., (1967) found that $50 \%$ had become blind in both eyes at the end of 5 years. In the treatment of diabetic retinopathy by pituitary destruction, regression of retinal new vessels has been one of the most important effects (Joplin et al., 1965); for only rarely can considerable improvement be achieved by correcting diabetic 
control, and then only if previous control had been particularly poor (Dollery and Oakley 1965). New vessels on the optic disc may likewise threaten vision; indeed a more serious prognosis has been attributed to new vessels if situated in this position (Dobree, 1964; Deckert et al., 1967). The effectiveness of photocoagulation still awaits the support of controlled studies, while the hazards of damaging adjacent tissue usually preclude it as a direct treatment for new vessels on the disc.

Patients with diabetic retinopathy treated by yttrium-90 needle implantation into the pituitary gland and non-operated control patients have been regularly followed in our clinic with assessment of visual acuity and retinal photographs to ascertain the value of pituitary ablation. It has not been ascertained whether new vessels on or emanating from the disc respond to pituitary destruction in the same way as do those on the rest of the retina. The present study investigates this issue by comparing progress of new vessels on the disc with the progress of those on the rest of the retina both in the operated and control patients; however it is not the purpose of this study to detail the effects of operation or the natural history of diabetic retinopathy when involving the disc. This is being comprehensively reported elsewhere (Kohner et al., 1970).

\section{Patients Studied}

Studies were made on 22 eyes from 16 patients who had been treated for diabetic retinopathy with pituitary implantation, drawn from the series reported by Oakley et $\alpha l$. (1969). In addition, studies were made on 7 eyes with diabetic retinopathy of equivalent severity from 7 patients in the control group. Five of these were randomly selected controls and 2 were elective control patients who had declined operation.

The criteria for selection of eyes for the present investigation were that good quality retinal photographs were available from before and at least 6 months after yttrium-90 implantation (range 6-22 months, mean 14 months) or a corresponding period for the controls (range 10-18 months, mean 14 months); secondly, that there were new vessels on the disc in the photographs taken just before operation, or on entry to the control group. Thirdly, only those eyes in which the new vessels appeared flat on the disc were included, as the response of these could well differ from new vessels growing forward into the vitreous. Finally, only eyes with new vessels on the disc of severity equal to or worse than the lowest standard (vide infra) and not associated with significant fibrosis were included. The chosen eyes were all those which fulfilled the above criteria out of a total of 105 consecutive patients treated by pituitary ablation and 40 controls. Six eyes of implanted patients and 3 of control patients which were originally suitable for study had become unassessable because of vitreous haemorrhage before the minimum period of follow up had elapsed, and hence cannot be reported on. No eye showed forwards proliferation of vessels during the study period.

Yttrium-90 pituitary ablation was carried out by the method of Fraser and Joplin (1961). On endocrine testing 3 months later (Joplin et al., 1965) it was found that 12 of the 16 patients were maximally ablated; this means a post-implant $48-\mathrm{h}^{131} \mathrm{I}$ uptake of under $21 \%$; steroid dependence; maximum growth hormone on an insulin tolerance test $<2 \mathrm{ng} / \mathrm{ml}$ and a significant fall in requirement of insulin (where applicable). Three patients had intermediate ablation, i.e. some but not all the criteria for "maximal" were reached. One patient showed no evidence of hypopituitarism.

\section{Methods of Assessment}

The eyes were studied by means of "Kodachrome" retinal photographs taken with a Zeiss camera giving a $30^{\circ}$ arc. The fields recorded were those of Joplin et al. (1965).

\section{a) New vessels arising on the disc}

The new vessels arising on the disc were rated in severity by comparison with standard photographs of such new vessels (vide infra). It was conceivable that new vessels arising on the disc might behave differently in that part of their course lying on the disc, from the more peripheral part of their course where they extended across the retina; hence the new ressels in these two zones were analysed separately. The vessels in the former zone were designated as "new vessels on the disc", and those in the latter as "disc new vessels extending across the retina". The latter were only rated to a distance of one disc diameter beyond the dise margin.

The severity of the new vessels in each of the two zones was graded by comparison with a corresponding set of standard photographs. Both sets consisted of 3 selected photographs $\mathrm{A}, \mathrm{B}$ and $\mathrm{C}$ showing new vessels of readily appreciated increasing severity. One set was selected to show "new vessels on the disc", and the other set to show "disc new vessels extending across the retina". They were used to grade the new vessels in patients' photographs as follows:

Grade 0: none

Grade 1: less than standard A

Grade 2: equal to or worse than A but less than B Grade 3: equal to or worse than $B$ but less than $C$ Grade 4: equal to or worse than C.

The pre and post operative gradings for the operated patients, and the corresponding gradings for the control patients will be referred to as the first and second assessments. These were first made by one observer (RSE) and then checked against independent ratings by another observer (GFJ) who was ignorant 
of whether the photographs were of operated or control patients, and which were the first and second assessments. There were no disagreements in the direction of change, and in about three-quarters of eyes, the absolute gradings were in agreement. Disagreements were resolved and a consensus rating used.

\section{b) New vessels arising on the retina}

To provide data on the simultaneous progress of the new vessels arising on the general retina, two other Zeiss camera photographic fields were graded numerically for new vessels by us according to the Hammersmith grading system (Oakley et al., 1967).

Corrected visual acuity had been recorded at the time the photographs were taken. A numerical grading was given according to the scheme of Joplin et al., 1967; the greater the severity of visual loss, the higher the grade value.

\section{Results}

a) Comparison of progress of new vessels arising on the disc with those arising on the retina (Fig. 1)

Considering all the 29 eyes studied, whether treated or controls, the direction of change for new ressels on the disc tended to follow that for new vessels on the general retina. Indeed there was only one eye in which progress of new vessels arising in the retina and of visual acuity. It is seen that in this group of 22 eyes there was a significant regression of disc vessels, both on and extending beyond the disc. Also there was a clear regression of retinal new vessels. Viscual acuity was not significantly improved $(p=0.39)$.

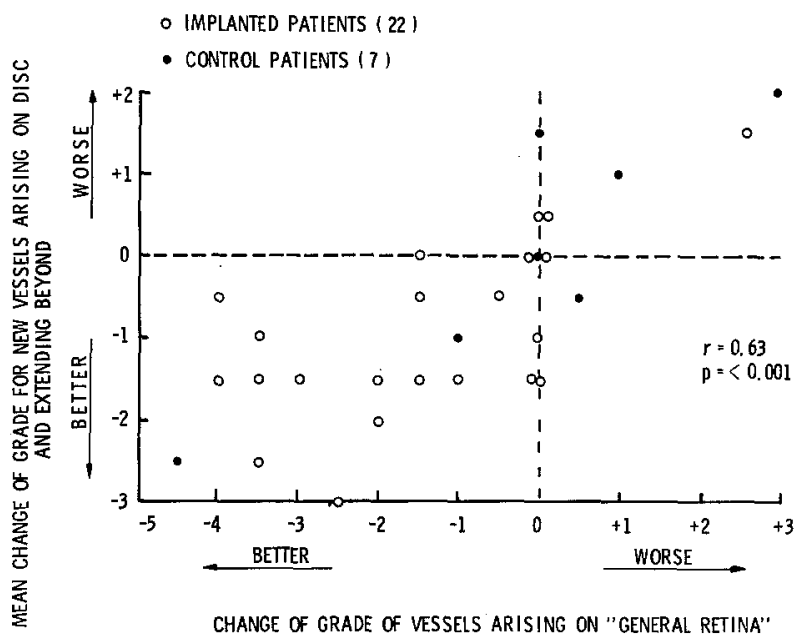

Fig. 1. Comparison of the changes of new vessels arising on the disc with new vessels arising on the general retina. All eyes studied whether operated or control are shown together

Table 1. Mean values ( \pm s.e.) for severity of new vessels arising on the optic disc and a) 22 eyes of 16 implanted patients.

\begin{tabular}{|c|c|c|c|c|}
\hline & $\begin{array}{l}\text { New vessels aris } \\
\text { course on disc }\end{array}$ & $\begin{array}{l}\text { sing on disc } \\
\text { course beyond } \\
\text { disc }^{\mathrm{a}}\end{array}$ & $\begin{array}{l}\text { New vessels } \\
\text { arising on gen- } \\
\text { eral retina }{ }^{\mathrm{a}}\end{array}$ & Visual acuity \\
\hline $\begin{array}{l}\text { Pre } Y^{90} \\
\text { Post } Y^{90}\end{array}$ & $\begin{array}{l}2.50 \pm 0.12 \\
1.54 \pm 0.22\end{array}$ & $\begin{array}{l}2.22 \pm 0.26 \\
1.31 \pm 0.24\end{array}$ & $\begin{array}{l}3.02 \pm 0.24 \\
1.59 \pm 0.19\end{array}$ & $\begin{array}{l}3.19 \pm 0.46 \\
2.71 \pm 0.39\end{array}$ \\
\hline \multirow[t]{2}{*}{$\begin{array}{l}\text { Pre vs. post } Y^{90} \\
\text { b) } 7 \text { eyes of } 7\end{array}$} & $\begin{array}{c}p<0.005 \\
\text { control patients. }\end{array}$ & $p<0.005$ & $p<0.0001$ & $p>0.05$ \\
\hline & $\begin{array}{l}\text { Now vessels aris } \\
\text { course on dise }\end{array}$ & $\begin{array}{l}\text { sing on dise } \\
\text { course beyond } \\
\text { disc }\end{array}$ & $\begin{array}{l}\text { New vessels } \\
\text { arising on gen- } \\
\text { eral retina } a^{\mathrm{a}}\end{array}$ & Visual acuity \\
\hline $\begin{array}{l}\text { First assessment } \\
\text { Second assessment }\end{array}$ & $\begin{array}{l}2.28 \pm 0.42 \\
2.28 \pm 0.28\end{array}$ & $\begin{array}{l}1.42 \pm 0.52 \\
1.85 \pm 0.40\end{array}$ & $\begin{array}{l}1.9 \pm 0.58 \\
1.1 \pm 0.40\end{array}$ & $\begin{array}{l}2.57 \pm 0.81 \\
3.57 \pm 0.97\end{array}$ \\
\hline $\begin{array}{l}\text { First vs. second } \\
\text { assessment }\end{array}$ & $p>0.05$ & $p>0.05$ & $p>0.05$ & $p>0.05$ \\
\hline
\end{tabular}

a It is to be noted that the absolute values in these 3 columns are based upon 3 different sets of standards and hence cannot be directly compared.

new vessels in these two areas changed in opposite directions. For this analysis, the rating for new vessels arising on the disc was the mean of the grading for "on the disc" and for "dise vessels extending across the retina", as 27 of the 29 eyes had disc vessels in both zones.

\section{b) Operated patients}

The progress of disc vessels is summarized in Table 1, and also shown here is the simultaneous
The progress of the disc vessels is shown for individual eyes in Fig. 2. Sixteen of the 22 eyes showed regression. Only two eyes showed an increase in vessels on the disc, one being from the patient in whom operation had failed to produce any suppression of pituitary function. Four eyes remained unchanged, two being from 2 patients who sustained only an intermediate degree of pituitary ablation.

Among the 16 eyes showing regression of disc vessels, the adjacent retina remained. free of fibrous 
retinitis proliferans in 14; one showed a new fibrous streak adjacent to the disc in association with preexisting dise vessels that had extended on to the retina; in the other an existing streak in a similar position became more obvious.
New vessels on the disc have been reported to progress to retinitis proliferans more rapidly than do those on the general retina (Dobree, 1964). Furthermore their occurrence is not uncommon. In a series of 112 eyes with retinopathy characterized by the presence

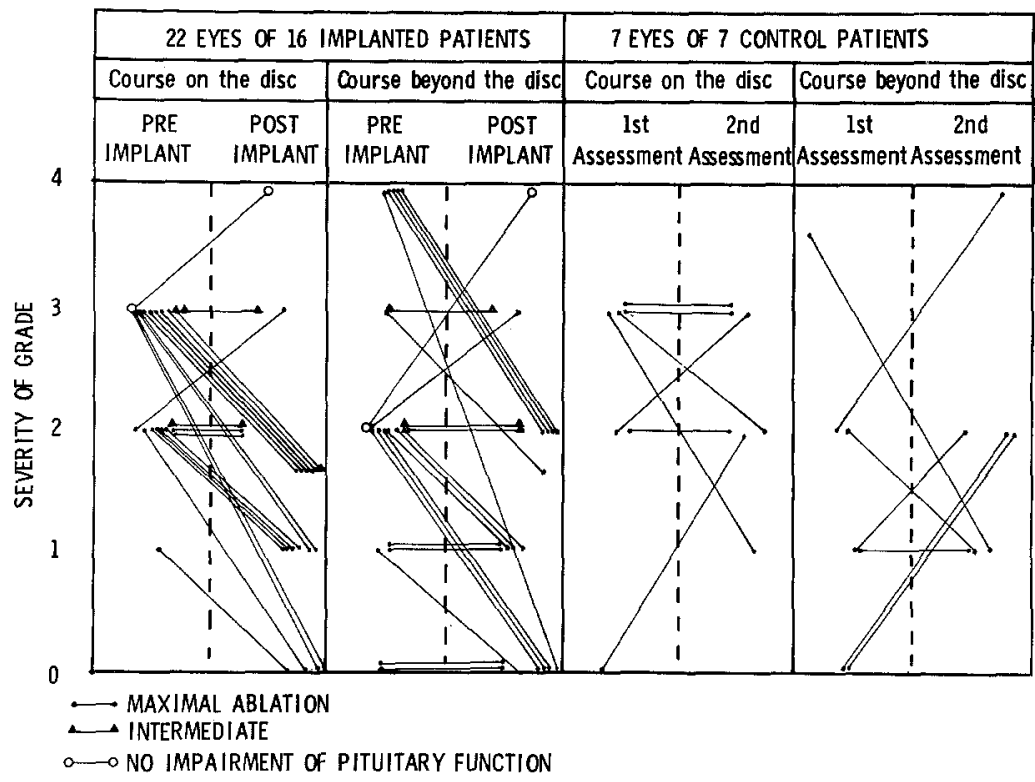

Fig. 2. Progress of new vessels arising on the optic disc

\section{c) Non-operated patients}

It is shown in Table 1 that this group of 7 eyes showed no significant change in disc vessels, retinal vessels, or acuity. Two eyes showed an improvement both in the disc new vessels and those disc vessels extending onto the retina (Fig. 2). In both these patients there had been a striking improvement in diabetic control.

\section{d) Progress of visual acuity}

While there was no significant improvement in visual acuity in the operated group $(p=0.39)$ there was probable deterioration $(p=0.06)$ of this parameter in the non-operated group (Table 1). Out of the 22 eyes showing change in both visual acuity and disc vessels, 15 showed these changes in the same direction.

\section{Discussion}

Our study has shown that flat new vessels confined to the disc and dise vessels where spreading beyond it, follow a course similar to those on the general retina in a group of operated and control patients. They usually regress following pituitary ablation, in a similar manner to those arising elsewhere on the retina. It should be remembered, however, that we studied only those cases without significant retinitis proliferans present on the disc before treatment, and the response might have been quite different had this not been the case. of new vessels, Dobree (1968) found that in $57(50.9 \%)$ there were new vessels present on the disc. Special consideration was accorded to new vessels on the disc in the Airlie House classification of diabetic retinopathy (1969). Since they are not amenable to direct treatment by light coagulation, and unless spectacular improvement in diabetic control could be expected, they might appear to constitute a special indication for pituitary ablation. Clearly new vessels of the type we have studied should not be regarded as a contra-indication to this form of treatment. It is emphasized that in this study only those new vessels which appeared to be flat on the disc were included. A separate study is being undertaken (Kohner et al., 1970) to determine the response to pituitary ablation of new vessels growing forwards into the vitreous.

Acknowledgements. We would like to express our thanks to Dr. E.M. Kohner and Professor T. Russell Fraser for their helpful criticism of the manuscript, and to all our collaborators named in the references who have con. tributed to the management, treatment and documentation of the parent series from which our material was drawn. We would also like to express thanks to the British Diabetic Association for a grant providing a technician to help with retinal photography.

\section{References}

Airlie house classification of diabetic retinopathy. In: Symposium on treatment of diabetic retinopathy. Edited by Goldberg, M.F. and Fine, S.L. U.S. Public health service publication No. 1890 (1969). 
Deckert, T., Simonsen, Sr., E., Poulsen, J.E.: Prognosis of proliferative retinopathy in juvenile diabetes. Diabetes 16, 728-733 (1967).

Dobree, J.H.: Proliferative diabetic retinopathy. Evolution of the retinal lesions. Brit. J. Ophthal. 48, 637-649 (1964).

- Evolution of lesions in proliferative diabetic retinopathy: An 8 year photographic survey. In: Symposium on treatment of diabetic retinopathy. Edited by Goldberg, M.F. and Fine, S.L. U.S. Public health service publication No. 1890 , p. 55 (1969).

Dollery, C.T., Oakley, N.W.: Reversal of retinal vascular changes in diabetes. Diabetes 14, 121-127 (1965).

Fraser, T.R., Joplin, G.F.: Therapeutic pituitary ablation. In: Modern trends in endocrinology. Edited by $\mathrm{H}$. Gardiner-Hill. p. 69-83 (1961).

Joplin, G.F., Fraser, T.R., Hill, D.M., Oakley, N.W., Scott, D.J., Doyle, F.H.: Pituitary ablation for diabetic retinopathy. Quart. J. Med. 34, 443-462 (1965).
- Oakley, N.W., Hill, D.W., Kohner, E.M., Fraser, T. R.: Diabetic retinopathy II. Comparison of disease remission induced by various degrees of pituitary ablation. by $\mathrm{Y}^{90}$. Diabetologia 3, 406-412 (1967).

Oakley, N.W., Hill, D. W., Kohner, E.M., Fraser, T.R. Diabetic retinopathy I. The assessment of severity and progress with a set of standard fundus photographs. Diabetologia 3, 402-406 (1967).

- Joplin, G.F., Kohner, E.M., Blach, R., Hartog, M., Fraser, T.R.: The treatment of diabetic retinopathy by pituitary implantation of radioactive yttrium. In: Symposium on treatment of diabetic retinopathy. Edited by Goldberg, M.F. and Fine, S.L. U.S. Public health service publication No. $1890,317-329$ (1969).

Dr. R.S. Elkeles

Dept. of Medicine

Royal Postgraduate Medical School

London, W.12

England 